\title{
ANALYSIS OF USING CODE SWITCHING IN INSTAGRAM
}

\author{
Kamariah $^{1}$ \\ Universitas Putera Batam (UPB), Batam, Indonesia \\ Email: pb141210172@upbatam.ac.id \\ Ambalegin ${ }^{2}$ \\ Universitas Putera Batam (UPB), Batam, Indonesia \\ Email: Ambalegin@puterabatam.ac.id
}

\begin{abstract}
The phenomenon of code switching nowadays is very often encountered in both direct and indirect communication or on social media. This research aims to describe the forms and the factors of using code switching that using in on Instagram. After doing the analysis researcher consider there are three kinds of form code switching that found on instagram account using by instagram users they are: tag-switching, intersentential code switching, and intrasetential code switching. Then after doing the analysis based on of the types, researcher founds the reasons of using code switching there are four points: changing topic, lack of vocabulary, bilingual/multilingual, Prestige and trend. This research using sociolinguistic study because it's related to the topic in this research. Then the researcher used qualitative research methods in doing the analysis. This research are expected to be useful in the process of learning language, especially studies of sociolinguistic and the using of language.
\end{abstract}

Keywords: tag-switching, intersentential code switching, and intrasetential code switching.

\section{INTRODUCTION}

Language is one of the communication tools used by humans to communicate or share ideas, thoughts, feelings, emotions, and so on. In various communities in the world, there are some people who have the ability to use more than one language. Such events are known as bilingual or multilingual. Such people are likely to change the language they speak while they speak. This phenomenon is known as 'codeswitching'. 'Code-Switching' can occur because language is one of the most important forms of human behaviour symbol and an important component of a group's identity.

Code switching is not just a phenomenon in a society where every member uses more than one language, but also a necessity in that society. Code switching is used to transfer the meaning to the interlocutor. When the language used by a speaker in conveying a meaning or message cannot be understood by interlocutor, then the speaker needs to change the language used in another language that can be understood by the recipient of the message or interlocutor.

People often unaware of their compilation using code switching. we often see the use of code switching in daily communication such as when talking with friends, in work, or in the teaching and learning process. in addition to daily communication, code switching is also often used in communication on social media such as; Facebook, Line, Whatsap, Instagram, Twitter, etc. Code switching occurs because there is a different language from each person, so sometimes to convey a message requires a switch to another language so that it can be understood by the recipient of the message. 
In bilingual, even multilingual, 'code-switching' communities are common. 'Code-switching' occurs when someone changes the language used in communicating. They use a language in a certain part and re-use the language they use in other parts (Holmes, 2013). Code-switching 'generally takes place in an informal situation while talking about everyday life, friends, family, and so on. In formal or official situations, 'code-switching' usually occurs in working communication at school or college. They often don't aware when they use code switching. This phenomenon not only occur in daily communication, but also can be found in communication on social media such as ; Facebook, Line, Whatsap, Instagram, Twitter, etc.

In this study, researchers are interested to analyses the using of code switching used by Instagram users and some factors cause code switching on instagram. The data in this study will be taken from several posts, comments, and conversations conducted by Instagram users. This research is expected to be useful in the process of learning language, especially studies of sociolinguistic and the using of language. Therefore in this research, researcher decided to choose code switching as a topic of discussion because the author realizes the importance of using code switching in bilingual or multilingual communication.

\section{LITERATURE REVIEW}

\subsection{Sociolinguistic}

Sociolinguists study the relationship between language and society. They are interested in explaining why we speak differently in different social contexts, and they are concerned with identifying the social functions of language and the ways it is used to convey social meaning (Lillis, 2013). So we can say that sociolinguistic is study of the process of language change caused of culture, religion, and other thing that related to the society in using of language. Because of that sociolinguistic is very important to analysis the relationship between language and society

Socio-linguistics is an interdisciplinary science between sociology and linguistics, two fields of empirical science that have very close links. Therefore, it is necessary to know in advance what is sociology and linguistics. Sociology is an objective and scientific study of humans in society, institutions, and social processes that exist in society. This study tries to find out how the community happened, is on-going and still exists. Linguistics is a field of science that studies languages or fields of science that take language as the object of study.

Sociolinguistics very useful in human life especially in communication and language. because language as a means of verbal communication in humans has certain rules. In its use, sociolinguistic provides knowledge of how to use language in certain social aspects or aspects. First, sociolinguistic knowledge can be utilized in communication or interacting. Second, sociolinguistics provides guidelines for communicating by showing the language, language variety or style of language that must be used when talking to certain people. As an object in sociolinguistics, language is not seen or approached as language but rather as a means of interaction or communication in human society.

Based on some sociolinguistic explanation above, it was concluded that sociolinguistics is one of the subdisciplines of linguistics that examines 
the relationship between language usages that occurs in society. Sociolinguistics studies all matters relating to the language used by a person in establishing social relationships and social life.

2.2. Code switching

Language can be a barrier to someone to communicate or it can be a way of success in life. Someone who cannot interact to other by using the target language, of course, will be difficult to adapt later on. Meanwhile, for those who are able to speak the target language will have good relation to others (Mubarak, 2019). Every culture has its own language, so these cultural differences lead to differences in language. Sometime the speaker experienced trouble to transferring the meaning to the inculcators, that's way the speaker need to switch the language to other.

A speaker may similarly switch to another language as a signal of group membership and shared ethnicity with an addressee. Even speakers who are not very proficient in a second language may use brief phrases and words for this purpose (Holmes, 2013). Code mixing occurs due to language contact between two groups of speakers of different languages. Language contact between the two different groups of speakers can occur in the fields of religion, trade, science and politics, art activities, economics and social activities. In this interaction there will be different cultural contacts so that it can influence the use of language.

The study of code-switching is the practice of switching between two or more languages within a single utterance (Zhiganova, 2016). The speaker switch from one language to other language, it happens when the meaning of the language can't be understandable by inculcators. Code switching needed to covering the meaning of the language, so that a conversation will be understandable between speaker and inculcators.

2.3. Types of code switching

People must select a particular code whenever they choose to speak, and they may also decide to switch from that code to another or to mix codes even within sometimes very short utterances (Wardugh, 2015). If someone has the ability to speak more than one type of language will be more likely to switch codes. However, not all people who speak several languages switch codes because this is also seen in terms of what the speaker wants to achieve.

According to (Stockwell, 2007)

There are three kind of code switching, they are: tag-switching, Intrasentential switching and Intersentential switching.

a) Tag-switching

Tag switching is the simple form of code switching because in this form the speaker tags and certain set phrases or words in one language are inserted into an utterance otherwise in another. Tag switching often happens caused of the lacked if vocabulary.

b) Intrasentential switching

This form is often occur when the conversation changed the topic Intrasentential switching occur within a clause or sentence boundary. It can take the form such as, code changing, code mixing, insertion and congruent lexicalizations.

c) Intersentential switching, in which a change of language occurs at sentence levels, where each clause or sentence is in one language or the other.

2.4. The reasons for switching

Code switching often occurs in communication of society, it happens 
when the meaning of conversation isn't understandable. Then the speaker need to switch one code to another's. In this research, researcher found some reasons that caused of code switching:

- Changing topic

Sometime the speaker need to switch the language when the topic of conversation is changed. For example:

"We are in class now studying English, bisa gak kamu dating kerumahku nanti after the class finish?"

- $\quad$ Lack of vocabulary

The lack of vocabulary between speaker and interlocutor when in conversation caused the speaker need to switch the language to other language.

For example: can you open the door?

What is the door?

The door is pintu in bahasa?

- Bilingual and multilingual

Multilingual and bilingual also caused the speaker switch from one language to others. For example: "I speak in English everyday, but saya juga bisa berbahasa Indonesia dengan baik".

Prestige and trend

In modern era people are able to communicate to others people in the world, so that they think that it's cool when more than one language.

For example:" kamu harus follow back aku ya"

From describing above, we can conclude that many reasons why people using code switching in their conversation, but the point to make it clear what is the meaning that they want to say to the listener, it relation to the situation and the topic.

\section{RESEARCH METHOD}

This research is descriptive research because in this research aims to describe the form and the factors of using code switching that using in on Instagram. Then in this research researcher use sociolinguistic study to analyze code switching that using in on Instagram. The data in this study will be taken from several posts, comments, and conversations conducted by Instagram users.

Analyzing data is a process of resolving data into its constituent components to reveal its characteristic elements and structure. In this research, researcher collects the data from instagram by using screenshot. Then researcher edit the photos that have taken from instagram, so that the conversation in the photo is clearly readable. Next, there are some analyses process such as read the conversation and underline it.

\section{RESULT AND DISCUSSION}

\subsection{Result}

After doing the analysis, researcher found three kind of code switching that used on instagram, they are:

\section{Tag switching}

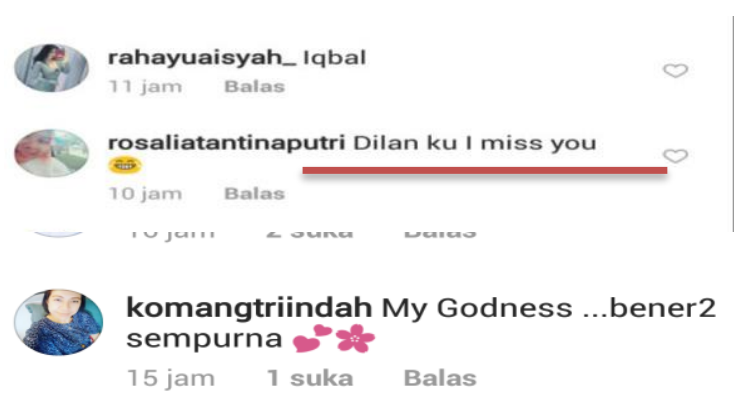

\section{Intersentential code switching}

$$
\begin{aligned}
& \text { Disukai oleh ayutingting92, egha_friyana dan } \\
& \text { 104.478 lainnya } \\
& \text { ivan_gunawan Setiap karya tercipta memiliki cerita } \\
& \text { yg berbeda.... busana dengan cutting clasik saya } \\
& \text { pilih untuk tema kali ini @love_ivangunawan } \\
& \text { \#ivangunawan \#tindonesiandesigner \#bridalgown } \\
& \text { \#bridalfashion }
\end{aligned}
$$


hardianislamiahputri Happy bday kakak...smg pnjang umur dan mudah rejeki....

kamariahriah96@hardian_islamiah_putri Amiin, makasih iyan

71 suka

sheltymaatuil Sisa kemarinn... Selamat

berbahagia sampai maut memisahkan " TILL THE

END OF TIME"

3. Intrasentential code switching

"Hi guys, tolong folback aku dong!!!"

Beb, udah aku follow ya ,tolong follow back"

" nanti Direct Message ke aku aja уа..”

ika_hassana Fokus nya sama si baby

Rafa 0 : 8

$2 \mathrm{hr} 1$ suka Balas

\subsection{Discussion}

1.

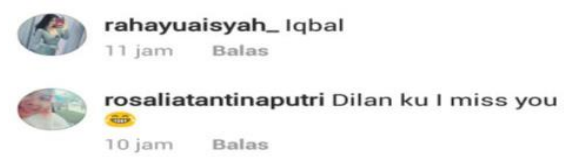

The type of code switching in data above is considered as Tag switching, because the conversation above using a sentence "I miss you" but in the beginning sentence the speaker using Indonesian word "Dilanku" the switched to English. It is considered as Intra-word switching because as we know Tag word switching when the speaker changes the code in form of words.

2.

Disukai oleh ayutingting92, egha_friyana dan 104.478 lainnya

ivan_gunawan Setiap karya tercipta memiliki cerita yg berbeda .... busana dengan cutting clasik saya pilih untuk tema kali ini @love_ivangunawan \#ivangunawan \#indonesiandesigner \#bridalgown \#bridalfashion

The type of code switching in data above is considered as Intersentential switching, because in this conversation used Indonesian then switched in

English word "cutting classic", as we know that Intersentential switching is the switched of code that occurs at sentence levels, where each clause or sentence is in one language or the other.

3.

@imanusman, ngobrolin pendidikan! Now all good things have to come to an end, and we have decided to end it with a blast! Gue bersama lineup komplit Ruangguru Squad akan hadir bersama di atas panggung untuk pertama kali di Bekasi!!! Gue udah liat rundown acara dan bakal beda banget.

The types of code switching above is categorized into Intersentential switching, because in this post switched between Indonesian sentences ("ngobrolin pendidikan ") and English's sentences ("now all good things have to come to an end, and we have decided to end it with a blast!"). Intersentential switching is in which a change of language occurs at sentence levels, where each clause or sentence is in one language or the other.

4. "Hi guys, tolong folback aku dong!!!"

The type of code switching in data above is considered as Intrasentential switching. The conversation above using "Hi guys" then switched to Indonesian in form of sentence "tolong folback aku dong 'because of that it categorize as Intrasentential switching, in which switches occur within a clause or sentence boundary. It can take the form such as, code changing, code mixing, insertion and congruent lexicalizations

5. Beb, udah aku follow ya ,tolong follow back"

The type of code switching in data above is considered as Intrasentential switching, because using Indonesian "Beb, udah aku" in the beginning sentence then switched to "follow" and 


\section{"follow back" . Intrasentential} switching, in which switches occur within a clause or sentence boundary. It can take the form such as, code changing, code mixing, insertion and congruent lexicalizations

6. " " nanti Direct Message ke aku aja уа.."

The type of code switching in data above is considered as intra sentential code switching, because the sentence above switched Indonesian "nanti....ke aku aja" and into English "Direct Message". As we know that Intrasentential switching, in which switches occur within a clause or sentence boundary. It can take the form such as, code changing, code mixing, insertion and congruent lexicalizations

7.

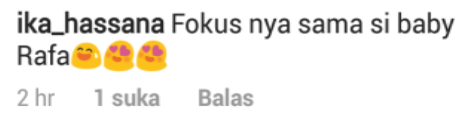

The type of code switching in data above is considered as intra sentential code switching. The sentence in the picture above used an Indonesian sentences "fokusnya sama si..." then switched to English " baby Rafa” so it consider into Intersentential switching, in which a change of language occurs at sentence levels, where each clause or sentence is in one language or the other.

8.

komangtriindah My Godness ...bener2 sempurna

$15 \mathrm{jam} 7$ suka Balas

The type of code switching in data above is considered as Tag-switching, because the sentence above used Indonesian phrase "bener 2 sempurna" which is means very perfect. So it is categorize into tag-switching, in which tags and certain set phrases in one language are inserted into an utterance otherwise in another.

9.

hardianislamiahputri Happy bday kakak...smg pnjang umur dan mudah rejeki....

kamariahriah96@hardian_islamiah_putri Amiin, makasih iyan

The type of code switching in data above is considered as Intersentential switching, because the sentence in the picture above using English "happy birth day .." then switched to Indonesian sentence "semoga panjang umur dan murah rejeki”. Intersentential switching, in which a change of language occurs at sentence levels, where each clause or sentence is in one language or the other.

10.

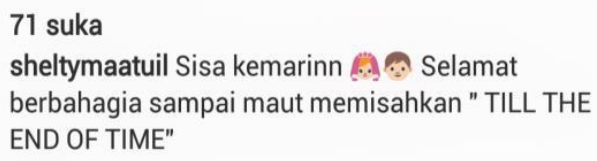

The type of code switching in data above is considered as Intersentential switching, in which a change of language occurs at sentence levels, where each clause or sentence is in one language or the other. The sentence above use Indonesian sentence " sisa kemarin, selamat bebahagia sampai maut memisahkan" then switched to English “ TILL THE END OF TIME”.

\section{CONCLUSION}

Based on analysis above the researcher conclude that code-switching is a term in linguistics referring to using more than one language or variety in conversation. code switching described as a skill of the bilingual speaker when communicate. Sometimes the bilingual 
speakers getting problem when they having a conversation with another bilingual, because of that they need to switch their language from one language to other language so that the interlocutors able to understand the meaning. In this research found three kinds of code switching that using in instagram account they are: tagswitching, intersentential code switching, and intrasetential code switching.

Based on of the types and analysis, researcher founds reasons of using code switching there are four points:

- Changing topic

- Lack of vocabulary

- Bilingual/multilingual

- $\quad$ Prestige and trend

\section{REFERENCES}

Holmes, J. (2013). An Introduction to Socialinguitstic fourth edition (Fourth edi). USA: Routledge.

Lillis, T. (2013). The Sociolinguistics of Writing. Edinburgh: Edinburgh University Press Ltd.

Mubarak, Z. H. (2019). The Analysis Of Repetition As Part Of Lexical Cohesion In Talk Shows. Jurnal Basis, 6(1), 81-94. https://doi.org/10.33884/basisupb.v 6 i1

Stockwell, P. (2007). Sociolinguistics a Resource Book for Students (Second Edi). New York: Routledge.

Wardugh, R. (2015). An Introduction to Socialinguistic (seventh ed). UK: Blackwell Publishing Ltd.

Zhiganova, A. V. (2016). The study of the perception of code-switching to English in German advertising. Procedia - Social and Behavioral Sciences, 236(December 2015), 225-229. https://doi.org/10.1016/j.sbspro.20 16.12.011 
Vol. 6 No.2 Dctober 2019

e-ISSN : 2406 - 9809 p-ISSN : 2527 - 8835

http://ejournal.upbatam.ac.id/index.php/basis

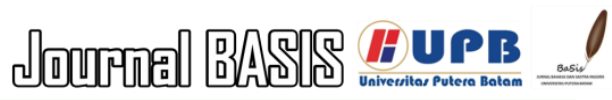

266 | P a g e 